\title{
A magyarországi makedonisztika
}

\author{
RITA KUZDER \\ Eötvös Loránd Tudományegyetem Bölcsészettudományi Kar, \\ Múzeum körút 4-6,HU-1088 Budapest, krita67@gmail.com
}

SCN VIII/2 [2015], 82-93

\begin{abstract}
V prispevku o makedonistiki na Madžarskem so najprej obravnavani zgodovinski stiki obeh narodov, nato pa so kronološko predstavljena makedonska literarna dela, objavljena od leta 1814 do danes. Med njimi najdemo literarnozgodovinska dela, predavanja o makedonski književnosti, članke o makedonskih pisateljih in nagrajencih makedonskih literarnih festivalov, intervjuje itn. Pozornost je posvečena tudi pomembnim prevajalcem leposlovja, zlasti Paskalu Gilevskemu, Zoltánu Csuki, Románi Gimes in Annamáriji Czinege - Panzova.
\end{abstract}

In this paper on Macedonian studies in Hungary, I first describe the historical relationship between these two nations in broad terms. This summary is followed by an outline of all Macedonian literary works published since 1814, in chronological order. Included in this historical outline of Macedonian literature are summaries of the history of literature, lectures on Macedonian literature, news about Macedonian writers and the prize-winners of Macedonian literary festivals. I also highlight the work of the most notable translators, i.e., Pascal Gilevski, Zoltán Csuka, Romána Gimes and Annamária Czinege-Panzova, who plays an important role even today.

Ključne besede: madžarska književnost, makedonska književnost, Paskal Gilevski, Zoltán Csuka, Blaže Koneski, prevajalci leposlovja

Key words: Hungarian literature, Macedonian literature, Pascal Gilevski, Csuka Zoltán, Blaze Koneski, translation work

A magyar és a makedón nép közötti kapcsolat története már több mint ezer éves. Jelen írásomban viszont az irodalmi kapcsolatok feltárására vállalkoztam, a tudományos nyelvészeti munkákat most nem vizsgáltam. Hosszú kutatómunka előzte meg a tanulmányom megírását. Személyesen kerestem fel Szkopjében a magyarországi makedonisztika kulcsfiguráját, Paszkál Gilevszkit. Ahogy Juhász Ferenc fogalmaz róla:

Paszkál Gilevszki egy embernyi Magyarország Macedóniában. És megfordítva: egy embernyi Macedónia Magyarországon. Szellemivé szorozva ezt a meghatározást: Pa- 
szkál Gilevszki a magyar költészet jelenléte Macedóniában, és megfordítva: a macedón költészet állandó jelene hazánkban. ${ }^{1}$

Számos fordítás - makedón nyelvről magyar nyelvre és fordítva - kötődik az ő nevéhez. Felvettem a kapcsolatot az Égei Makedónok Magyarországi Szövetségével, a Magyar Írószövetséggel, és a Macedón Nagykövetséggel. (Dolgozatomban a makedón kifejezést használom - a macedón helyett - a nép és a nyelv megnevezésére, míg az ország nevét Macedónia formában írom. A magyar helyesírás ezt megengedi, ugyanakkor a makedónok makedón nyelven így nevezik magukat, nem téve különbséget az ókori makedón nép és nyelv megnevezésétől. Úgy találtam, hogy ez a különböző irodalmi forrásokban, újságokban sem következetes, még ugyanannál a szerzőnél sem. A makedón tulajdonneveket az akadémiai szabályzat szerint, fonetikusan írtam át.)

Paszkál Gilevszki 1939-ben született az Égei Makedóniában, Görögországban, Szetoma faluban. A Széchenyi Irodalmi és Művészeti Akadémia székfoglaló beszédében lehet olvasni az első lejegyzett történelmi kapcsolatról a két nép között, mely eseményröl egy költeményt is írt (Gilevszki 1985: 17-21). Hiteles történelmi forrásokból tudjuk, ${ }^{2}$ hogy I. Szent István királyunk lánytestvérét, Szamoil cár kérte fiának, Gavril Radomírnak feleségül. De ő később várandós feleségét hazaküldte 3 (Györffy 1983: 285), mert a görög rabnőjébe volt szerelmes, aki 985-től volt a „tulajdona”. Körülbelül 25 év elteltével a makedónok követséget küldtek Magyarországra a herceghez, Petar Deljanhoz, hogy álljon seregük élére, mint trónörökös, s vezesse a csapatot az öket sanyargató konstantinápolyi császár ellen. Sajnos árulás miatt a csatát elvesztették 1040-ben, ahol a trónörökös is meghalt (Györffy 1983: 286).

A 14. században a törökök előrenyomulása miatt sokan, makedónok, szerbek, bolgárok, görögök, albánok menekültek Magyarországra. ${ }^{4}$ A későbbiekben, a 15.-16. században néhányan közülük magas tisztséget töltött be a fejedelmi udvarokban. Közéjük tartozott a humanista Macedóniai László (Obermayer és Horváth 1959: 773) püspök, aki kiterjedt kulturális tevékenységet folytatott magyar és német területen. A makedón nyelvü könyveket Magyarországon nyomtatták mind az itt élő makedónok számára, mind pedig a Macedóniában élők számára, ahogy ezt Hász Magdolna kéziratában olvashatjuk.

\footnotetext{
${ }^{1}$ Juhász Ferenc köszöntőbeszéde Paszkál Gilevszkinek a Magyar Széchenyi Irodalmi és Művészeti Akadémia tagjává választása alkalmából 1996-ban (Paszkál Gilevszki a szerzőnek adta a kéziratot).

${ }^{2}$ A következő tudományos munkák ismertetik a hiteles történelmi forrásokban leírtakat: Moravcsik 1934: 182, Fehér 1927-28: 7-11, Zlatarsi 1932: 354-363, Vajay 1967: 65-67, 87.

${ }^{3}$ Más források szerint olyan veszélyes volt a helyzet a Balkánon, hogy biztonsági okokból küldte Magyarországra, ennek ellentmond az, hogy később István haddal vonult a makedónok ellen, megtorolni a sérelmet.

${ }^{4}$ Markó királyfi (1335-1395) két fivére is Zsigmond királyhoz menekült.
} 
A 18.-19. században nagyszámú macedón, szerb és bolgár élt Magyarországon. A számukra nyomtatott könyvek közül csaknem 200 található a Szt. Kliment Ohridszki Nemzeti és Egyetemi Könyvtárban (Национална и Универзитетска Библиотека „Св. Климент Охридски”), Szkopjében. Többségük Budán, az egyetemi nyomdában készült, amely 1795-ben cirill betűs tipográfiát vásárolt. A Szkopjében lévő művek közül a legrégibb 1798-ban, a legkésőbbi 1878-ban jelent meg, túlnyomó részük a 19. század első harmadában. Pesten Josif Barmel nyomdájában is készültek könyvek; Landerer nyomdájában latin betüs kiadványok láttak napvilágot /.../ (Hász: kézirat).

A makedón irodalom szempontjából az első fontos dátum 1814, amikor Budán elkezdték nyomtatni az első makedón nyelvü könyveket. Ekkor adták ki Joakim Krcsovszki $A$ halálról szóló beszéd (Слово исказаное заради умирание) címü könyvét és második művét, az Elbeszélés Krisztus rettenetes második eljöveteléröl címü könyvét (Повест ради страшнаго и втораго пришествија Христова), mely északkeleti makedón nyelvjárásban volt megírva. Ezt követően a további három könyve is Budán lett nyomtatva.

Krcsovszki könyveiben már kitapintható a nyelv helyes fejlödésének az iránya, bár szövegeit még átszövik az egyházi szláv elemek. Öt, jórészt imádságokat, valláserkölcsi oktatásokat, prédikációkat és legendákat tartalmazó könyve 1814-19 között Budán és Pesten jelent meg. (Csuka 1963: 141)

Ugyanitt Budán, a Magyar Királyi Nyomdában nyomtatták 1816-ban Kiril Pejcsinovics Тӥkör (Огледало) címü alkotását, melyet tetovói nyelvjárásban írt meg a szerző.

A könyvet a makedón kereskedők és polgárok támogatásával adta ki. A parasztok nehéz helyzetét ecseteli, hevesen támadja a káros népszokásokat (iszákosság), s a felvilágosodás eszméit igyekszik terjeszteni. Könyvei több kiadást értek meg, szívesen másolták is öket. (Csuka 1963: 141)

1840-ben jelent meg a Bünösök vigasztalása (Утешение грешним) címü könyve. Erről a müről Blazse Koneszki így írt: „Irodalmunk első olyan alkotása, amely az eredetiség jegyeit hordozza" (Koneszki 1967: 23).

Az elmúlt évezredben több hullámban érkeztek hazánkba török, vagy egyéb politikai elnyomás elől menekülő makedónok. A utolsó ilyen hullám az 194749-es görög polgárháború idején volt, amikor számos égei makedón hagyta el Görögországot, és települt le Magyarországon. E szomorú esemény egyik következménye volt viszont, hogy később az idemenekült és itt tanult makedónok munkássága nyomán lassan kialakult a magyarországi makedonisztika.

\section{Magyar nyelven megjelent makedón irodalom kronológiai sorrendben}

A magyarul megjelent makedón irodalmi alkotásokat kronológiai sorrendben ismertetem. Némelyikről csak a címe és a megjelenési év az összes információm. Mindössze az utolsó két regényről lehet olvasni recenziókat, ezeket ott jelzem is. 
A magyarországi makedonisztika kezdetekben nagyrészt két személy munkásságára épül, Paszkál Gilevszki és Csuka Zoltán (1901-1984) esszéire, verseire és fordításaira. Az első magyar nyelven megjelent makedón novella, Szlavko Janevszki: A ló, a lány meg a sors (Коњот, девојката и судбината - Vujicsics 1960: 345-355) címü írása volt Csuka Zoltán fordításában 1960-ban. Ezt követően mind Magyarországon - bár itt kevesebb - mind Macedóniában szinte évente megjelent egy-egy fordítás.

Csuka Zoltán: A jugoszláv népek irodalmának története (Csuka 1963) könyvét 1963-ban adták ki. A függelékben Kozocsa Sándor és Radó György által összeállított $A$ jugoszláv irodalom magyar bibliográfiáját is megtalálhatjuk (Kozocsa és Radó 1963). A könyv a délszláv irodalom kitünő összefoglalása történelmi korszakokra bontva (a kezdetektől 1963-ig), és kihangsúlyozva a jugoszláv népek főbb politikai, társadalmi, irodalmi és nyelvi eseményeit, főbb irodalmi alkotóit.

Magyarul Örök várakozó címmel Újvidéken jelent meg 1964-ben Aco Sopov verseiből egy válogatás Fehér Ferenc fordításában és Kovács János szerkesztésében (Sopov 1964).

Szintén Újvidéken jelent meg 1966-ban magyar nyelven egy kötetben négy elbeszélés négy makedón szerzőtől. Szlavko Janevszki: A legsötétebb erdö (Најмрачната шума); Vidoe Podgorec: A néma fiú (Молчиото момче); Gligor Popovszki: Éjszaka a folyón (Ноќ на реката); Nedzsati Zekerija: A körhinta (Рингишпилот) címü történeteket tartalmazza a kötet (Janevszki, Podgorec, Popovszki és Zekerija 1966).

Érdemes megemlíteni, hogy ebben az időszakban Paszkál Gilevszki két előadást tartott a Magyar Tudományos Akadémián. 1968 decemberében A mai makedón irodalom, 1973 januárjában pedig Petöfi költészetéröl és hatásáról a makedón irodalomra címmel. 1973-ban az újvidéki Hungarológiai Intézet Tudományos Közleményeiben megjelent Petöfi a macedón költészetben címü rövid írásában (Gilevszki 1973: 77-78) ismerteti mely makedón költőkre (Georgi Sztalev, Szlavko Janevszki, Aco Sopov, Gane Todorovszki, Aco Karamanov, Volcse Naumcsevszki és mások) milyen hatást gyakorolt híres költőnk munkássága.

A szó születése. Mai makedón költők címủ antológia 1969-ben látott napvilágot, Csuka Zoltán és Paszkál Gilevszki szerkesztésében. Tizenöt költő több versét mutatja be a könyv kiváló magyar költők, úgymint Ágh István, Garai Gábor, Illyés Gyula, Juhász Ferenc, Képes Géza, Nagy László, Somlyó György, Weöres Sándor és az újvidéki Ács Károly és Fehér Ferenc múfordításában (Csuka és Gilevszki 1969). Az utószóban így fogalmaz Csuka Zoltán: „Blazse Koneszki többé-kevésbé még a hagyományos költészet művelőjének számít, a fiatalabbak azonban már az avantgardisták eredményeit hasznosítják költészetükben" (Csuka és Gilevszki 1969: 179).

\footnotetext{
${ }^{5}$ Paszkál Gilevszki mindkét beszéd kéziratát a szerzőnek adta.
} 
Ugyanitt, a kötetben bemutatott valamennyi költőről és stílusjegyeiről írt pár sorban egy rövid ismertetőt. Ez volt az első olyan kötet, mely áttekintő képet ad magyarul a makedón költészetröl.

Fordításaiból állította össze jugoszláv lírai antológiáját Csillagpor címmel Csuka Zoltán, mely 1971-ben jelent meg Csuka Zoltán és Paszkál Gilevszki szerkesztésében ezúttal tizenegy költő versét olvashatjuk a makedón költők címszó alatt (Csuka és Gilevszki 1971).

Vidoe Podgorec A szöke cigánygyerek (Белото циганче) címü ifjúsági regényét 1973-ban publikálták Újvidéken magyar fordításban (Podgorec 1973).

Jovan Pavlovszki Sárfészek (Тоа Радиовие во кое паѓам длабоко) címü regénye 1976-ban Újvidéken jelent meg magyarul Csuka Zoltán fordításában (Pavlovszki 1976).

Már Budapesten adták ki 1978-ban Kocso Racin Fehér hajnalok (Бели мугри) címü elbeszélését (Racin 1978).

Dávid András Délszláv epikus énekek magyar történeti hösök címủ tanulmánya 1978-ban jelent meg (Dávid 1978). A tanulmány a délszláv epikus énekhagyomány magyar vonatkozású anyagának azzal a részével foglalkozik, amelyben a 14. és a 16. század közötti időszak történelmi szempontból hiteles és tetteiknél fogva kimagasló magyar személyekröl fennmaradt jelentős költészeti emlék. A szerző mintegy négyszáz éneket gyüjtött össze és használt fel müvében, mely felöleli az egész délszláv nyelvterületet, így természetesen makedón vonatkozásokat is találhatunk a könyvben. Azokkal a történeti személyekkel foglalkozik, akiknek sokrétű, közvetlen kapcsolatuk volt a délszláv népekkel. Így szól tehát Nagy Lajosról (Kralj Laus), Ozorai Piporól (Filip Madzsarov), Jagello Ulászlóról (Kralj Vladiszlav), Székely Jánosról (Banovics Szekula), Hunyadi Jánosról (Szibinjanin Jankó), Szilágyi Mihályról (Mihailo Szvilojevics), Mátyás királyról (Kralj Matijas) és Dóczy Péterről (Petar Dojcsin).

A nyolcvanas években nagyobb számban jelentek meg makedón nyelvről magyarra fordított könyvek, mint korábban. Dusko Nanevszki A táltos ló (Самовилското коњче) címü makedón népmesék könyve 1980-ban Budapesten látott napvilágot (Nanevszki 1980). S még ugyanebben az esztendőben publikálták Blazse Koneszki válogatott verseit a Markó temploma címü kötetben (Koneszki 1980). A könyvben szereplő verseket Paszkál Gilevszki válogatta és Ács Károly, Csuka Zoltán, Dudás Kálmán, Fehér Ferenc, Illyés Gyula, Képes Géza, Nagy László, Rab Zsuzsa, Tandori Dezső fordította. Utószóban Paszkál Gilevszki így ír a makedón tudós, költő és író óriásról, aki a makedón nép újabb történelmének egyik legjelentősebb személyisége.

/.../ költészete egy viharos lélek, egy nagy szellem kohéziójában született; a költő teljes élményvilága, minden élettapasztalata néhány markáns vonalba, néhány lendületesen ívelő ecsetvonásba sürítve. /.../ Költői nyelve csodálatos, néha prózai, de mindig expresszív ritmikájú, rímei pompásak, váratlanul kirobbanóak, gondolatai mélyenszántóak, s keserüségükben is súlyosak. /.../ Ha kötött formát használ: pontos és szigorú, mint a népdal, ha szabadon ír: kötetlenül is tisztán artikulált, hajlékony és egyszerü, mint a népmese. (Gilevszki 1980: 106-107) 
A konzul éjszakája. Mai makedón elbeszélök címủ újabb válogatáskötetet 1981-ben publikálták Budapesten (Gimes 1981). Huszonhárom makedón elbeszélő novelláit ismerheti meg a magyar olvasóközönség négy fordító, Gimes Romána, Potoczky Klára, Nikowitz Oszkár és Poór Zsigmond munkáján keresztül. S még ugyanebben az esztendőben, Debrecenben jelent meg Zsivko Csingo Hogyan öltem meg a pajtásomat címmel válogatott elbeszéléseinek gyüjteménye (Csingo 1981). A könyvben huszonhárom elbeszélése olvasható magyar nyelven. Az utószót Milosevits Péter írta. Zsivko Csingo első kötete 1963-ban jelent meg Paszkvélia (Пасквелија) címmel, s a harmadik kötete A szerelmes szellem (Вљубен дух) volt, ez 1976-ban jelent meg. A magyarul megjelent válogatás Predrag Stepanović munkája, aki ezekből az elbeszéléskötetekből merített, s ezzel egyidejüleg Csingo novellisztikájának keresztmetszetét is nyújtotta.

Magyarul elöször 1982-ben olvashattuk Tasko Georgievszki Fekete vetés Falak (Црно семе-Sидови) címmel két regényét (Georgievszki 1982). Mindkét regény a görögországi polgárháború idején, illetve utána játszódik. A Fekete vetés főhőse, egy egyszerü makedón paraszt, aki a történelmi események ártatlan áldozataként kerül egy kopár szigetre, ahol aláírást akarnak kierőszakolni tőle, hogy nem kommunista. Igaz sosem volt az, de mégsem írja alá, mert józan paraszt eszével úgy okoskodik, ha aláírja, később majd azt csinálnak vele, amit akarnak. A Falak főhőse visszatér falujába a polgárháború után, s háza romjai helyén nekiáll újjáépíteni azt. A regény címe szimbolikus: a falakat újjá lehet építeni; de a falak egyben egymást szerető és gyülölő embereket is elválasztanak. Még ebben az évben egy verses kötet is megjelent magyarul Mile Nedelkoszki versei címmel (Nedelkoszki 1982).

Paszkál Gilevszki A dal élete (Gilevszki 1985) címü válogatott verses kötetét 1985-ben adták ki Budapesten. A verseket maga a költő válogatta és Ács Károly, Ágh István, Brasnyó István, Bella István, Csuka Zoltán, Gereblyés László, Fehér Ferenc, Jung Károly, Lator László, Pap József, Pór Judit, Székely Magda és Weöres Sándor fordította.

Újvidéken és Budapesten is megjelent 1986-ban Mateja Matevszki Esők (Дождови) címü verseskötete (Matevszki 1986). A verseket válogatta és az utószót írta Paszkál Gilevszki, fordította Ács Károly, Ágh István. Mateja Matevszki kötetéröl az utószóban így fogalmaz Paszkál Gilevszki:

/.../ közelinek, ismerősnek éreztem és megbarátkoztam vele. De nemcsak én: kortársaim és barátaim is, akikkel akkoriban kezdtünk írogatni. Az Esők című kötet, Blazse Koneszki Hímzö lánya és Gane Todorovszki Nyugodt léptekje mellett mindennapos, nélkülözhetetlen olvasmányunkká vált. Az Esőkből tanultunk meg korszerúen gondolkozni és írni. /.../ Matevszki vállalja, hogy hatottak rá a világirodalom egyes költői, mint például Lorca vagy Whitman. Mégis, költészetének fő forrása, igazi ihletője az eleven élet, a természet, gyermekkorának vidéke, a kövek, méhkaptárok, a zöld rétek, kék hegyek, egyszóval, a szülőföld. Éppen ezért Matevszki, amellett, hogy az első modern makedón költő, Blazse Koneszki, Gane Todorovszki és Ante Popovszki mellett ő egyik legnemzetibb költőnk is. (Gilevszki 1986: 101-103) 
Az 1990-es években alábbhagy a nagy fordítói munka. Mindössze három újságcikket olvashatunk a makedón irodalommal kapcsolatban. A Magyar Nemzet 1992. április 3-ai számában A szó születése. Makedón írók Budapesten címmel publikáltak egy cikket, melyben Ferch Magda interjúvolta meg Paszkál Gilevszkit a témával kapcsolatban. Az Új Magyarország 1993. október 21-én Bognár Antal cikkét közölte Örzők a strázsán. Borostaviziten Paszkal Gilevszkinél címmel. 1993. május 5-én megalapították az Égei Makedónok Magyarországi Szövetségét Szentendrén Koszta Andreov vezetésével. A tagok minden év március 15-én összejövetelt szerveznek, hogy megemlékezzenek a magyar ünnepről, hasonlóképpen augusztus 2-án a makedón ünnepről. De rendeztek már a Magyar Müvelődési és Közoktatási Minisztérium, illetve a Petőfi Irodalmi Múzeum segítségével könyvkiállítást is a Szt. Kliment Ohridszki Nemzeti és Egyetemi Könyvtárban a szkopjei egyetemen müködő magyar lektorátussal együttmüködve, ahol a fellelhető magyarul megjelent makedón és makedónul megjelent magyar könyvek kerültek kiállításra. A harmadik cikk a Szövetség kiadványában, а Македонски извор (Makedon forrás) címü hírlapban jelent meg 1998 szeptemberében. Ebben a számban olvashatunk arról, hogy Juhász Ferenc elnyerte a Sztrugai Költői Estek Aranykoszorú díját. Ezt a díjat 1968ban Nagy László kapta meg. A Sztrugai Költői Estek idején, 1992-ben írták alá a Magyar Írószövetség és a Makedón Írók Szövetsége közötti együttműködési szerződést. A szerződést a két írószövetség elnöke, Jókai Anna és Jovan Pavlovszki látta el kézjegyével.

Meg kell jegyeznünk, hogy Juhász Ferenc Pupillák címü kötetében (Juhász 1995) megjelent Az Ohridi források címü nagy költeményében név szerint is megemlíti makedón költő és író barátait.

Az ezredforduló egy kis fellendülést hoz a makedón irodalom magyar nyelvre való átültetésébe is, az előző évtized visszaesése után.

Csuka Zoltán Egy égbolt alatt címü könyve 2001-ben jelent meg (Csuka 2001).

A szerző /.../ születésének 100. évfordulója e kötet szerkesztöit arra kötelezte, hogy föt hajtva a nagy tiszteletre méltó mü és ember előtt, számot adjanak a múltnak, a mának és a jövőnek verseiből és versfordításaiból. (Csuka 2001: 3)

A kötetben négy makedón szerzőtől is találhatunk versfordításokat.

Egy újabb múfordítás-kötetet publikáltak 2005-ben Budapesten, Balkáni kulcs. Harminchat macedóniai elbeszélö címmel. Az utószót írta és az elbeszéléseket fordította Hász Magdolna (Király 2005). A kötetben olvasható elbeszélések képet adnak Macedóniáról az olvasónak, az ott élö, sokat szenvedett népnek és nemzetiségnek az irodalmáról. A kötet érdeme, hogy Macedónia elbeszélés irodalmának több stílusrétegét megmutatja. Az írók közül a legidősebb 1920ban született, a legfiatalabb 1975-ben. Történelmi okai vannak, hogy a makedón irodalom fiatal, noha természetesen megvannak a gyökerei a népköltészetben, legendákban, mesékben, valamint a középkori egyházi irodalomban. Mindössze 1947-ben jelent meg az első, makedón irodalmi nyelven írt elbeszéléskötet, 
Jovan Boskovszki Kivégzés (Растрел) címmel. A makedón írók első nemzedéke (Sztale Popov, Vlado Maleszki, Kole Csasule, Szlavko Janevszki, Blazse Koneszki) már az ötvenes években megteremtették a realisztikus makedón irodalom alapjait. Az ötvenes évek második felében alkotó írókat (Szrbo Ivanovski, Petar Kosztov, Szimon Drakul stb.) a makedón irodalomtudomány „modernistáknak” nevezi. A „realistákkal” szembefordulva témában és kifejezésmódban is a sokszínűségre törekedtek. A „nagy generáció” a harmadik nemzedék (Petre M. Andreevszki, Vlada Urosevics, Tasko Georgievszki, Mile Nedelkoszki, Zsivko Csingo, Paszkál Gilevszki stb.) alkotásaikban a makedón föld és nép jelenik meg, a történelmük, a saját koruk, s mindig az ember, ahogyan megéli az eseményeket. Mindezek kifejezésére a legkülönbözőbb kifejező eszközöket használják, a népnyelvtől egészen a fantasztikumig. Atanasz Vangelov, Mitko Madzsukov, Luan Sztarova és mások tartalmi és formai újításokat alkalmaznak müveikben. A negyedik nemzedék (Krszte Csacsanszki, Dragi Mihajlovszki, Ermisz Lafazanovszki, Dragan Ilievszki, a filmrendező Milcso Mancsevszki stb.) már az ötvenes, hatvanas évek gyermekei. A világirodalom legmodernebb irányzatai hatottak stílusukra. Abszurd, groteszk, fantasztikus elemekkel gazdagították a makedón irodalmat. S a legfiatalabbak (Igor Isakovszki, Goce Szmilevszki, Szonja Mandzsuk stb.) ismét új témákkal, és stílussal jelentkeztek az irodalomban. A generációk között természetesen nincsenek éles válaszfalak, hisz a nemzedékek hatnak egymásra, tanulnak egymástól.

A szkopjei Szent Cirill és Metód Egyetem szervezte Nemzetközi makedón nyelvi, irodalmi és kulturális szeminárium fordítói csoportmunkája eredményeképpen Blazse Koneszki néhány novellájának nyolc nyelvre történő átültetése 2012-ben Szkopjéban jelent meg. Három novella (A csendes Don (Тивокот Дон), Találkozó a mennyországban (Средба на pajom), Találkozás (Средба)) magyar fordítását Hatala Tünde és Bólya Annamária készítette (Tasevszka 2012).

Ugyancsak 2012-ben jelent meg magyarul Czinege-Panzova Annamária kitűnő fordításában Goce Szmilevszki Freud húga (Сестрата на Зигмунд Фроjd) címü regénye (Szmilevszki 2012). A regény 2010-ben elnyerte az Európai Unió Irodalmi díját, s azóta több mint harminc nyelvre fordították le. A történet hiteles történelmi tényeken alapul. Sigmund Freud a fasizmus zsidóellenes eszméinek erősödésével, rettegő húgai folytonos kérésére sem segített nekik útlevelet szerezni és elmenekülni az országból, míg maga, családja, a család orvosa és annak családja valamennyien Freud segítségével menekültek Angliába. Mind a négy húga viszont a koncentrációs táborban lelte kínhalálát. A regény narrátora Adolfine, Freud legfiatalabb húga. A regényről írt recenziókból ${ }^{6}$ kitűnik, hogy a magyar olvasóközönség is megdöbbent, ugyanakkor érdeklödve olvasta a tehetséges fiatal makedón író regényét.

${ }^{6}$ Wirágh András, Tukacs Tamás, Kajó Cecília, Cserhalmi Imre írtak recenziót a műről (nem teljes a névsor, de az említésre méltóakat emeltem ki). A recenziók fellelhetőségét az irodalomjegyzékben megadtam. 
Anyja egyik születésnapján, amikor az annak idején a szélrózsa minden irányába szétszóródott testvérek családjukkal együtt újból egybegyülnek a szülői házban, Adolfine összepakol, és a Fészek néven ismert bécsi elmegyógyintézetébe vonul. Ezzel kezdetét veszi a regény legérdekesebb része, amelyben - holmi miniatür Varázshegy mintájára - nem történik semmi, de mégis sok minden történik. /.../ a regény eredetileg 1938ban veszi kezdetét, amikor a családjukat részben vagy egészében elvesztett nővérek a hitleri tisztogatásoktól rettegve bújnak össze a sötét hálószobában. Adolfine éppen hogy elmesélheti, hogyan hagyta őket cserben az időközben világhírü báty, aki családjával Londonba menekülhetett, egynéhány reflexiót követően a szöveg végigrohan egy rövid, de annál jelentősebb időszakon, majd az elbeszélő becsukott szemekkel már az utolsó lélegzetvételre vár egy haláltábor kamrájában. Az ezt követő fejezetekben az emlékfolyam a kora gyermekkorig vezet vissza, illetve innen halad a regény jelen ideje felé, amelyben minden egyes felbukkanó emlékkockának gyorsan tova is kell suhannia, hogy az utolsó visszatekintés az egész életet felölelhesse. Túlzás lenne azt állítani, hogy az élettörténet ebben a végzetes pillanatban kristályosodna ki egyetlen egésszé, hiszen Adolfine számára ekkor már nincsenek megértendő vagy megmagyarázandó események - a történetet tartalmazó könyv nyitva áll, az olvasást megkönnyítő sorvezetőt pedig akkurátusan odahelyezték a lapok közé. (Wirágh: 1993)

Egy ugyancsak Európai Unió Irodalmi díjas regényt is Czinege-Panzova Annamária fordítói munkáján keresztül ismerhetett meg a magyar olvasóközönség, nevezetesen Lidija Dimkovszka Tartalék élet (Резервен живот) címü müvét (Dimkovszka 2015), mely 2015-ben jelent meg Budapesten. A regény egy, a fejüknél összenőtt sziámi ikerpárról szól, akik csak felnőtt korukban tudják alávetni magukat a veszélyes szétválasztó mútétnek, mely sajnos egyikük tragikus halálához is vezet. A regény az ő életüket, mindennapjaikat, nehézségeiket, örömeiket mutatja be egyik szálon, míg a regény másik szála Jugoszlávia, szűkebben az akkori Szkopje hiteles történelmét mutatja meg realisztikus, már-már dokumentarista stílusban.

Összegzésképpen elmondhatjuk, hogy az elmúlt ötven évben mintegy majdnem hatvan makedón költő és író művébe nyerhettünk betekintést több fordító és müfordító kiváló munkáján keresztül.

Mindenképpen szeretném felsorolni azokat a kiváló költőket, írókat és müfordítókat, akik nagyszerü munkái nélkül nem ismerhettük volna meg a makedón irodalom fentebb felsorolt remekmüveit. Ök pedig Ács Károly, Ágh István, Brasnyó István, Bella István, Czinege-Panzova Annamária, Csuka Zoltán, Dudás Kálmán, Garai Gábor, Gereblyés László, Gilevszki Paszkál, Gimes Romána, Gyimót Ágnes, Fehér Ferenc, Fehér Kálmán, Hász Magdolna, Illyés Gyula, Juhász Ferenc, Jung Károly, Képes Géza, Lator László, Nagy László, Nikowitz Oszkár, Pap József, Pákozdy Ferenc, Poór Zsigmond, Pór Judit, Potoczki Klára, Rab Zsuzsa, Sády Erzsébet, Somlyó György, Szabó János, Szalai Zora, Székely Magda, Szilágyi Károly, Tótfalusi István és Weöres Sándor voltak. 


\section{BIBLIOGRÁFIA}

Antal BOGNÁR, 1993: Örzők a strázsán. Borostaviziten Paszkal Gilevszkinél. Új Magyarország III/246, 9.

Imre CSERHALMI, 2012: Az önkeresés és önvesztés regénye. Goce Szmilevszki: Freud húga. (Recenzió). Budapest. http://olvassbele.com/2012/10/28/az-onkereses-es-onvesztes-regenye-goce-smilevski-freud-huga/.

Zsivko CSINGO, 1981: Hogyan öltem meg pajtásomat. Budapest: Európa Könyvkiadó.

Zoltán CSUKA, 1963: A jugoszláv népek irodalmának története. Budapest: Gondolat.

- -, 2001: Előszó. Egy égbolt alatt. Érd: Csuka Zoltán Városi Könyvtár.

Zoltán CSUKA és Paszkál GILEVSZKI (szerk.), 1969: A szó születése. Mai makedón költők. Budapest: Európa Könyvkiadó.

- -, 1971: Csillagpor - Jugoszláv lírai antológia. Budapest: Magvető Kiadó.

András DÁVID, 1978: Délszláv epikus énekek-magyar történeti hösök. Újvidék: Forum Könyvkiadó és Budapest: Szépirodalmi Könyvkiadó.

Lidija DIMKOVSZKA, 2015: Tartalék élet. Budapest: Napkút Kiadó.

Géza FEHÉR, 1927/28: A bolgár egyház kísérletei és sikerei hazánkban. Századok $61-62,7-11$.

Magda FERCH, 1992: A szó születése. Makedón írók Budapesten. Magyar Nemzet $\mathrm{LX} / 80,10$.

Tasko GEORGIEVSZKI, 1982: Fekete vetés. - Falak. Budapest: Európa Könyvkiadó.

Paszkál GILEVSZKI, 1973: Petőfi a macedón költészetben. HITK 16-17, 77-80.

--, 1980: Utószó. Blazse Koneszki: Markó temploma. Budapest: Magvető Könyvkiadó.

- -, 1985: A dal élete. Budapest: Európa Könyvkiadó és Újvidék: Forum Könyvkiadó.

- -, 1986: Utószó. Mateja Matevszki: Esők. Újvidék: Forum Könyvkiadó és Budapest: Európa Könyvkiadó.

Romána GIMES (szerk.), 1981: A konzul éjszakája. Mai makedon elbeszélők. Budapest: Európa Könyvkiadó.

Romána GIMES (szerk.), 1982: Mile Nedelkoszki versei. Budapest: Európa Könyvkiadó.

György GYÖRFFY, 1983: István király és müve. Budapest: Gondolat.

Magdolna HÁSZ, é. n.: Hungarikumok a Macedón Tudományos Akadémián és a Kliment Ohridszki Nemzeti és Egyetemi Könyvtárban. Kézirat.

Szlavko JANEVSZKI, 1960: A ló, a lány meg a sors. Mai jugoszláv elbeszélők. Szerk. Sztoján D. Vujicsics. Budapest: Európa Könyvkiadó. 345-355.

Szlavko JANEVSZKI, Vidoe PODGOREC, Gligor POPOVSZKI és Nedzsati ZEKERIJA, 1966: A legsötétebb erdö. - A néma fiú. - Éjszaka a folyón. - A körhinta. Újvidék: Forum Könyvkiadó.

Ferenc JUHÁSZ, 1995: Pupillák. Budapest: Dunakanyar 2000 Könyvkiadó. 
Cecília KAJÓ, 2012: Goce Szmilevszki: Freud húga. (Recenzió). Budapest. http://konyves.blog.hu/2013/01/23/freud_huga_419.

Farkas KIRÁLY (szerk.), 2005: Balkáni kulcs. Harminchat macedóniai elbeszélő. Budapest: Napkút Kiadó.

Blazse KONESZKI, 1967: Za makedonszkata literatura. Szkopje: Kultura. 23.

- -, 1980: Markó temploma. Budapest: Magvető Könyvkiadó.

Sándor KOZOCA és György RADÓ (szerk.), 1963: A jugoszláv irodalom magyar bibliográfiája. Csuka Zoltán: A jugoszláv népek irodalmának története. Budapest: Gondolat.

Mateja MATEVSZKI, 1986: Esők. Újvidék: Forum Könyvkiadó és Budapest: Európa Könyvkiadó.

Gyula MORAVCSIK, 1934: A magyar történet bizánci forrásai. Budapest: Magyar Történelmi Társulat. 182.

Dusko NANEVSZKI, 1980: A táltos ló. Újvidék: Forum Könyvkiadó.

Erzsébet K. OBERMAYER és István Károly HORVÁTH, 1959: Macedóniai László. Egy humanista élete és müködése a Mohács körüli évtizedekben. Századok, 773-802.

Jovan PAVLOVSZKI, 1976: Sárfészek. Újvidék: Forum Könyvkiadó.

Vidoe PODGOREC, 1973: A szőke cigánygyerek. Újvidék: Forum Könyvkiadó.

Kocso RACIN, 1978: Fehér hajnalok. Budapest: Európa Könyvkiadó.

Aco SOPOV, 1964: Örök várakozó. Újvidék: Forum Könyvkiadó.

Goce SZMILEVSZKI, 2012: Freud húga. Budapest: Libri Könyvkiadó.

Roza TASEVSZKA (szerk.), 2012: Blazse Koneszki 1921-1993: Forditás nyolc nyelvre (A csendes Don - Találkozó a mennyországban - Találkozás). Szkopje: Univerzitet Sv. Kiril i Metodij. 8, 12, 17.

Tamás TUKACS, 2012: „,Mi hát az örültség?”- Goce Smilevski: Freud húga. (Recenzió). Budapest. http://kulter.hu/2013/01/mi-hat-az-orultseg/.

Szabolcs VAJAY, 1967: Géza nagyfejedelem és családja. Székesfehérvár Évszázadai 1. $65-67,87$.

Sztoján VUJICSICS (szerk.), 1960: Mai jugoszláv elbeszélők. Budapest: Európa.

András WIRÁGH, 2012: Homokszemben a világ - Goce Smilevski Freud húga. (Recenzió). Budapest: Tiszatáj. http://tiszatajonline.hu/?p=17797.

Vasil ZLATARSI, 1932: Wer war Peter Deljan? Annales Academiae Scientiarum Fennicae 27, 354-363. 


\section{MAKEDONISTIKA NA MADŽARSKEM}

V prispevku o makedonistiki na Madžarskem so sprva orisani tisočletni zgodovinski odnosi in stiki med dvema narodoma. Izpostavljeno je leto 1814, ko je bila v Budimu natisnjena prva knjiga $\mathrm{v}$ makedonščini (Joakim Krčovski: Pridiga o umiranju). Med letoma 1947 in 1949 so številni Egejski Makedonci zaradi grške državljanske vojne zapustili Grčijo in se naselili na Madžarskem; posledično se je na Madžarskem začela razvijati tudi makedonska književnost. $\mathrm{V}$ prispevku so v kronološkem vrstnem redu predstavljena vsa doslej objavljena makedonska knjižna dela. V delih, naštetih v članku, najdemo npr. povzetke zgodovine književnosti, predavanja o makedonski književnosti, novice o makedonskih pisateljih in dobitnikih nagrad na makedonskih knjižnih festivalih, poročila itn. Izpostavljena so tudi dela še danes pomembnih prevajalcev, npr. Pascala Gilevskega, Zoltána Csuka, Románe Gimes in Annamárie Czinege - Panzova. Številni madžarski pesniki in prevajalci knjižnih del so zaslužni, da je ljubiteljem književnosti postala dostopna tudi makedonska poezija v madžarščini. 